\title{
Embedded librarianship and Blackboard usage to manage knowledge and support blended learning at a South African university of technology
}

\author{
Lynn Kleinveldt ${ }^{1}$, Marietjie Schutte ${ }^{2}$ and Christine Stilwell ${ }^{3}$ \\ lynn.kleinveldt@gmail.com ORCID: orcid.org/0000-0001-7537-7548 \\ marietjie.schutte@up.ac.za ORCID: orcid.org/0000-0001-7148-563X \\ stilwell@ukzn.ac.za ORCID: orcid.org/0000-0002-1372-9576
}

\begin{abstract}
Received: 22 June 2016
Accepted: 05 August 2016
\end{abstract}

\begin{abstract}
The purpose of this study was to investigate how Cape Peninsula University of Technology (CPUT) Libraries can contribute to knowledge management processes using the Learning Management System, Blackboard, by embedding the librarian in the learning environment to support blended learning. Structured interviews were conducted at CPUT with eight lecturers involved in the Extended Curriculum Programme (ECP) in Faculty $A$ and with one Faculty $A$ librarian. One of the main findings indicated that lecturers use various teaching methods to support ECP students. Knowledge sharing between lecturers and the librarian mainly takes place during meetings and via email, but not via Blackboard. Training on Blackboard and current awareness of features such as Blackboard Collaborate are needed. Departments within Faculty A considered working together with the faculty librarian to support ECP students essential; they found it beneficial, important and very useful. Departments perceived Blackboard as a communication platform as well as a useful teaching tool. Both positive and negative experiences were shared about the use of Blackboard in the ECP. Although lecturers and the librarian thought that Blackboard improved student learning, both were aware of other means of reaching the students online such as Facebook or Google. Overall, there is a good working relationship between lecturers and the librarian with regard to supporting ECP students. It is therefore important that parties seeking collaboration should create an appropriate platform for interaction. One of the limitations of the study is that it excludes the student experience of using the online learning environment at CPUT. The study could inform CPUT Libraries and the university community regarding improving knowledge management practices.
\end{abstract}

Keywords: Embedded librarianship, Blackboard, blended learning, Knowledge Management, Learning Management Systems, collaboration

\section{Introduction and background}

The importance of knowledge management (KM) practices and processes are widely recognised. There is a great need for organisations, especially academic institutions and their libraries, to capture and store knowledge in order to retrieve and utilise it for the creation of new knowledge. Knowledge management processes are crucial for building strong cultures within universities (Aharony 2011: 111, Kille 2006: 94, Mavodza \& Ngulube 2012: 2). Academic libraries, institutions' storehouses of knowledge, play a vital role in contributing to their university community (Moll \& Kleinveldt, 2008: 2). The rise of Web 2.0 and emerging technologies have placed academic libraries in a good position to become innovative and, in many cases, placed them at the forefront of embracing technologies to support the goals of their parent institutions. Embedding librarianship in the online learning environment, in particular, is an example of academic libraries being innovative in embracing technologies to support teaching and learning.

An online learning environment can be defined as a platform that facilitates teaching and learning through various online classroom activities (Tu 2002: 34). Online learning environments are also referred to as Course Management Systems (CMS), Virtual Learning Environments (VLE) and Learning Management Systems (LMS) and include products such as Blackboard (Ball et al. 2012, Costello, Lenholt \& Stryker 2004: 452, Hightower, Rawl \& Schutt 2007: 542, Yen et al. 2015: 141). Courses that exist within an online learning environment allow for greater partnership between librarians and lecturers in supporting teaching and learning. The purpose of Blackboard is to encourage and/or improve online teaching and learning, sharing, and collaboration between students and lecturers. It has been argued that online learning environments such as Blackboard are a 'plug and play' online classroom setting, where teaching becomes static and textual, meaning that content designed for online learning may not change for a long period of time (Coopman 2009). Nevertheless, online learning environments complement traditional face-to-face teaching, creating spaces for learning to take place beyond the boundaries of the physical classroom. The combination of both approaches is known as blended

1. Lynn Kleinveldt is a faculty librarian at the Cape Peninsula University of Technology, Cape Town, South Africa. She is a M.IT graduate of the University of Pretoria

2. Marietjie Schutte is a lecturer in the Department of Information Science, University of Pretoria

3. Christine Stilwell is Professor Emeritus in the Information Studies Programme, University of KwaZulu-Natal, South Africa 
learning, and carefully combines the physical and online classrooms (Crocker 2006: 3). Blended learning is defined as the "thoughtful integration of classroom face-to-face learning with online learning experiences" (Anderson \& May 2010: 497). The advantage of using online learning environments is that they give students the opportunity to access and revise the content of modules multiple times, anytime and anywhere. Online learning environments create an opportunity for librarians to embed themselves in the space of the lecturers and students, in order to provide support to them.

Embedded librarianship plays an important role in supporting blended learning at higher education institutions in particular. However, 'embedded librarianship' has different meanings, which can cause some confusion. It can refer to a librarian situated physically or virtually in a classroom or a department to provide information support for a particular course to students and academic staff (Hoffman 2011: 453, Si et al. 2012: 176). For the purposes of this study, an embedded librarian refers to the librarian being present in the online course to assist students with information queries and to suggest relevant sources relating to the course; the librarian should be actively involved online in providing information support to both staff and students (Hoffman 2011: 444, Si et al. 2012: 176, University of North Carolina 2010).

The Cape Peninsula University of Technology (CPUT), founded in 2005 by the merging of the former Cape Technikon and Peninsula Technikon, is "the only university of technology in the Western Cape and the largest university in the region" (CPUT 2016a). A geographically-dispersed, dynamic and diverse institution, with a vision "to be at the heart of technology education and innovation in Africa" (CPUT 2016a), it started subscribing to the online learning environment, Blackboard, in 2006. However, engaging with online learning environments through support from the Centre for eLearning is reported to have been in practice since 2000 in the former Cape and Peninsula Technikons (CPUT 2016b). It is ideal to investigate whether Blackboard is an appropriate platform for knowledge management processes.

In an attempt to deal with high dropout rates across higher education institutions, especially in the first year of study, Extended Curriculum Programmes (ECP), funded by government, were introduced to provide additional academic support for students. ECP provided a foundation phases for courses. Students who would not previously have been accepted into universities were now able to gain entry to ECP, and thus received more time, less pressure and extra support in their programme of study (Garraway 2009: 54). In an ECP, the curriculum extends over a longer period; firstyear subjects are covered over two years (CPUT 2008). Additional modules such as English Communication, End-user Computing, Academic Literacy and Information Literacy (IL), are integrated into the curriculum, providing students with the skills needed to complete assignments in their core courses (Naidoo \& Raju 2012: 35). ECP in the South African context have experienced challenges, but strengths are also evident. Some of the challenges include time constraints in discipline-specific subject support; proper planning, which is needed in these extended programmes as only partial integration of additional tutorials is evident; and the expense of offering ECP. A strength of ECP is the educational development and growth of the student. If the programme is well-designed and there is good liaison between student and subject specialists, it could lead to successful curriculum reform, a larger group of diverse students could be reached, and retention could be improved (Clarence-Fincham 2009: 78). Support from units such as Fundani Centre for Higher Education Development (CHED) at CPUT, which supports lecturers in their teaching, are key in supporting ECP. Similarly, the academic library plays a vital role in supporting ECP; potentially to a greater extent in their online learning environments.

The purpose of this study, drawn from a dissertation undertaken by Kleinveldt as part of a Master of Information Technology (M.IT), was to investigate how Cape Peninsula University of Technology (CPUT) Libraries can contribute to knowledge management processes in an online learning environment (Blackboard), by embedding the librarian in the environment to support blended learning. A study of knowledge management practices, as well as methods being used at universities, contributed to this research. It is hoped that this study of CPUT Libraries will contribute to the role played in their institutions by other academic libraries.

\section{Theoretical framework and literature review}

Models for lecturer-librarian collaboration have become essential in academic institutions to enhance teaching and learning. Increased support from management is crucial for this sort of collaboration to be successful. The study drew on one such model, namely Shepley's (2009: 91), of which a core element is lecturer and librarian collaboration. This collaboration helps both parties as their shared goal is to ensure student success by working together to support teaching and learning. The model helps lecturers understand the librarians' role, as the librarian has the information skills and expertise that can help lecturers in updating their curriculum. In this context, librarians are seen as adding great value to the curriculum (Shepley 2009: 91, Veal \& Bennet 2009: 163). The dissertation by Kleinveldt (2015: 17) made reference to a study by Shepley (2009) who describes a model of collaborative course development between lecturers and librarians which was developed over a period of seven years at the Saskatchewan Institute of Applied Science and Technology (SIAST). The model entails a "commitment to the highest quality in course development, teaching and learning, recognition of individual expertise, trust and willingness to listen, and a sense of humour" (Shepley, 2009: 91). Important aspects of the model are expanded on in the literature review.

In terms of the conceptual framework for the study, a number of concepts were identified in the literature that deal with knowledge management and online learning environments at higher education institutions such as online distance learning and virtual learning environments (Levy 2003). The focus has shifted from a teaching perspective to one of collaboration and knowledge sharing within organisations; a move away from a 'top-down' management approach to a 'bottom-up' approach (Goh 2005:16). The four areas identified in the literature are discussed in the section that follows. 


\subsection{Lecturer and librarian collaboration in South Africa and internationally}

In higher education institutions worldwide, collaboration between lecturers and librarians is a common trend in reaching institutional strategic goals, especially in the areas of research support and teaching and learning. To achieve student learning success, collaboration between the various partners in the university community is imperative. Studies on lecturer and librarian collaboration conducted by Besara and Kinsley (2011: 418), Corrall (2010: 571), Massis (2012: 90), Shepley (2009: 91), Tenkasi and Boland (1996: 88) and Veal and Bennett (2009: 162) were very useful to this study.

Collaboration between librarians and lecturers can be described as two players - the lecturer with the subject expertise and the librarian with information and research knowledge - forming a team to teach and support student learning and development (Bhavnagri \& Bielat 2005: 122). Collaboration between different stakeholders in a university has become even more significant with the growing importance of "knowledge intensive firms" (Tenkasi \& Boland 1996: 88). This shift has led to universities having different collaboration models in place. An example of a library-led collaboration model between lecturers and librarians, highlighted in a study conducted at the Florida State University (Besara \& Kinsley 2011: 419), included IL training initiatives and the creation of spaces within the library, such as writing centres. In South Africa, a study by Thomas and Saib (2013: 8) emphasised how successful collaboration between lecturers and librarians led to the integration of IL into the curriculum of an engineering course at the Durban University of Technology (DUT). Some lecturers recognise the importance of IL and welcome collaborative initiatives with librarians (Oakleaf, Millet, \& Kraus 2011: 833). These collaborations demonstrate their recognition that support for teaching and learning, and lecturer and librarian collaboration, are vital (Massis 2012; Si et al. 2012). At CPUT, the approval of the IL policy in 2009 meant that it was necessary for academics to integrate IL into the curriculum. In response, the library offered faculties an IL Certificate Programme, which is a credit-bearing course. In addition, with librarians linked to the Blackboard pages of lecturers, IL modules with online assessments which students complete in Blackboard allow librarians to work more closely with lecturers to improve assignments and research projects in which students need to apply the IL skills taught.

\subsection{The use of online learning environments to share knowledge}

Examples of the use of online learning environments were identified in studies conducted by Rafaeli et al. (2004), Levy (2003), Comba (2009), Xiao (2010) and Menkhoff et al. (2011). Nielsen and McCabe (2012) addressed the concept of embedded librarianship as a means of lecturers and librarians sharing skills in an online learning environment to support student learning. Tenkasi and Boland (1996), in their study of an organisation using an online learning environment called SPIDER, found that the online learning environment was an ideal platform for knowledge sharing and could result in successful collaboration between stakeholders. The technology acts as an enabler of knowledge sharing, which leads to positive outcomes such as enhancing the working relationships between staff members in an organisation (Tenkasi \& Boland 1996: 88).

Barker (2006: 230) discusses how 'virtual communities' should be formed in order for knowledge sharing to take place within organisations and higher education institutions. She describes virtual communities as being formed in a "virtual world through virtual relationships": a team of individuals willing to assist one another in an online space (Barker 2006: 228). Kleinveldt (2015: 31) highlighted in her study that some authors claim that knowledge sharing tools are becoming more evident in online learning environments within organisations and higher education institutions (Menkhoff et al. 2011: 134, Tenkasi \& Boland 1996: 88). Therefore, through the interaction taking place via an online learning environment by individuals, knowledge sharing takes place, which results in virtual communities forming. This activity also acts as a form of virtual Community of Practice (CoP), which is discussed in section 2.3.

\subsection{Knowledge management in universities and their libraries}

A local example of knowledge management practices in higher education was identified by Mavodza and Ngulube (2012). Individuals are being encouraged to reuse knowledge developed by others within an organisation (Maponya 2005: 902). This practice points to the potential of a system like Blackboard to maximise communication and collaboration, highlighting the importance of the current study. Collaboration can also be seen in communities of practice (CoPs) in universities. First identified by Lave and Wenger (1991), a CoP can be described as a group of individuals who have the same interest, working together and sharing knowledge to achieve set goals (Sandrock 2011). Through its use of online learning environments, a CoP can be referred to as a virtual community, meaning that members sharing the same values, goals or problems engage via electronic communication (Barker, 2006: 229).

KM practices in universities and their libraries have become important in transforming universities into learning organisations. With higher education institutions being described as knowledge hubs, knowledge management is key to achieving their strategic goals (Maponya 2005: 901). KM practices are fundamental to libraries as well. There is, however, some uncertainty, pointed out by Mavodza and Ngulube (2012: 498), about how they actually improve the quality of services offered to users. Mavodza and Ngulube (2012) argue that KM has mainly been used in businesses for competitive advantage and profit making. However, libraries have been innovative by incorporating KM practices in creating new spaces for their users that are "inviting, dynamic and exciting", improving library staff performance through training and embracing emerging technologies. According to Mavodza and Ngulube (2012: 498), these practices entail, amongst other things, the "implementation of web-based services and tools that emphasise online sharing and collaboration amongst users". Thus, the online environment facilitates KM practices for libraries (Kleinveldt, 2015: 40).

In order to develop a greater understanding of the conditions and processes that help promote the sharing of tacit knowledge in a formal online learning environment setting, Tee and Karney (2010: 386) conducted a study of an online 
graduate business course offered at a private, non-profit university in the United States of America. Data was collected through interviews, observation, document and record analysis, and through unobtrusive measures such as posting trends on bulletin boards which were automatically captured by the online learning system. It was found that the online course encouraged processes consistent with Nonaka and Takeuchi's (1995) Socialization, Externalization, Combination, Internalization (SECI) model (Tee \& Karney, 2010: 386) which has made a core contribution to knowledge creation and information transfer theory.

\subsection{Lecturers and librarians sharing knowledge}

Creating a knowledge-sharing environment among lecturers can improve their knowledge and skills and the academic support they offer to students (Ngulube 2005: 57). The development of a knowledge-sharing framework was suggested by Ngulube (2005) in a study at the then-University of Natal in South Africa which investigated research procedures used by Master of Information Studies students between 1982 and 2002. The knowledge-sharing framework consists of systems thinking, learning organisation, innovative leadership, social capital, trust and teamwork (Ngulube 2005: 52). Maponya (2005: 904) held that social networks are crucial for knowledge sharing to take place in higher education institutions.

The aim of KM in academic libraries is to "promote knowledge innovation" (Jain 2007: 380). Librarians need to share their intellectual and operational knowledge in order to contribute to the learning organisation and the building of a knowledge culture within university libraries. However, the right climate needs to be created for knowledge sharing to take place. It is also important that partnerships are built with other external university libraries in order to share knowledge (Jain 2007: 380).

Academic librarians, now more than ever, are the 'go-to' persons in supporting teaching, learning and research (Mavodza 2011:447). One important factor supporting this statement is the integration of IL into the curriculum of courses, with the main focus to improve students' information-seeking skills to empower them to work independently. To remain relevant and avoid being victims of the "Panda Syndrome", which refers to pandas being "highly loved, and nearing extinction" (Mavodza 2011:447), librarians constantly and proactively need to update their knowledge and skills to respond to the needs of the university community, for example by supporting IL integration into curricula. Librarians who teach IL are expected to obtain higher and often specialised qualifications (Mavodza 2011:448). At CPUT Libraries, faculty librarians obtained the Train-the-Trainer qualification, an accredited facilitator's course, in preparation for designing modules and assessments for and then teaching the IL Certificate Programme. Knowledge sharing has become vital among librarians in the creation of information and knowledge, as well as interaction with lecturers. Research on knowledge sharing within different areas of an organisation has become more important, especially in universities where the focus is on building knowledge cultures (Liu, Chang, \& Hu 2010: 456). This approach fits in well with the aim of the current study, investigating knowledge sharing among librarian and lecturers in support of blended learning at CPUT (Kleinveldt 2015: 44).

Liu, Chang and $\mathrm{Hu}(2010: 456)$ state that, in the online environment, it has become even more important for librarians to share knowledge. This is evident at CPUT in faculty librarians currently being linked to the Blackboard pages of lecturers in order to upload IL training material and assessments, and the constant collaboration and knowledge sharing which takes place between the librarian and lecturers in order to support teaching and learning. Collaboration with lecturers is important, and librarians and lecturers share knowledge to support teaching, learning and research.

The above approaches formed the basis of this study, supporting the view that collaboration and knowledge sharing within the online learning environment is essential.

\section{Research question}

The purpose of the study was to investigate whether Blackboard could be used as a knowledge management tool between lecturers and embedded librarians to support blended learning at CPUT, with special reference to the Extended Curriculum Programme (ECP) students in Faculty A. The researchers formulated a research question on which the empirical study was based. The research question is: How is knowledge sharing between lecturers and librarians using online learning environments taking place to support first-year Extended Curriculum Programme students?

\subsection{Research sub-questions}

Through reviewing the literature, the research question was deconstructed to yield the following research sub-questions:

1. How is knowledge shared between lecturers and librarians?

2. How have online learning environments been used to share knowledge?

3. How are Extended Curriculum Programme students being supported in learning and success?

4. How have online learning environments been used to support ECP?

\section{Methodology and data collection}

The literature review focused on aspects relating to embedded librarianship, lecturer and librarian collaboration, the use of online learning environments to support teaching and learning, and knowledge sharing among lecturers and librarians at various universities internationally and nationally. The empirical aspect of the study focused on whether knowledge sharing was occurring at CPUT on Blackboard in supporting the blended learning of ECP students in Faculty A. The 
primary researcher conducted interviews with lecturing staff and the faculty librarian involved in teaching and supporting ECP students. The results section provides a discussion of how the findings from the empirical study contribute to and extend the literature review.

The population consisted of twenty-five lecturers across the eight departments in the faculty concerned, all involved in ECP. A sample of nine participants was selected through purposive sampling: one lecturer per department and one faculty librarian in Faculty A. Participants were interviewed once. Data were collected through structured interviews which were recorded. Some departments did not want to be interviewed, preferring to use the interview schedule as a selfadministered questionnaire. Thus, there are instances where departments declined to answer some questions.

The aim of conducting interviews was to find out about the lecturers' and faculty librarian's views and experiences in using an online learning environment to share knowledge (with other academics and librarians) in order to support students. The Blackboard system was introduced fairly recently to the institution, therefore, the aim of the study was to investigate how the lecturers and librarian are embracing this learning management system to enhance face-to-face class sessions, especially with regard to IL training. Conducting interviews with ECP lecturers was intended to give a deeper understanding of the situation pertaining to online learning environments and the sharing of knowledge between lecturers and librarians. It was hoped that the interview process would give insight into whether Blackboard could or was being used as a knowledge management tool to support blended learning, as well as the role the embedded librarian played.

As recommended by Silverman (2011: 274) and Clark and Creswell (2011: 187), in-depth and critical evidence about the online environment could be provided through structured interviews. The qualitative findings were analysed using these authors' recommended methods and included content analysis. Responses from the participants were grouped into themes and recorded in a table. A limitation of the study is that it excluded the student experience of using the online learning environment at CPUT. The study also examined a single faculty only.

\section{Findings and discussion}

The findings are discussed in two parts. The first part looks at the experiences of a selection of academic departments that teach ECP students in Faculty A. The second part looks at the experiences of the Faculty A librarian. The reason for the selection stems from the primary researcher's work as a faculty librarian actively involved in supporting lecturers in teaching, learning and research. After reviewing the literature on lecturer and librarian collaboration, knowledge management practices within universities, and on knowledge sharing among librarians and lecturers, it was decided that the method of gathering data would be conducting interviews with lecturers involved with the ECP in Faculty A and with the one Faculty A librarian at CPUT.

\subsection{Findings from departments}

The first section looks at the experiences of the eight departments. Questions which departments declined to answer have been left blank. The purpose of interviewing lecturers in the eight departments in the faculty concerned was to investigate whether the online learning environment, Blackboard, was being used as a knowledge management tool to support ECP students. Departments were labelled A-H. Table 1 illustrates themes identified from lecturers' responses on their role in supporting ECP student learning.

Table 1 Lecturers' role in supporting ECP student learning, by department

\begin{tabular}{|c|c|c|c|c|c|c|c|c|c|c|}
\hline Role & A & B & C & D & $\mathbf{E}$ & $\mathbf{F}$ & G & H & Total & $\begin{array}{c}\text { Percentage } \\
\%\end{array}$ \\
\hline Teach & $x$ & $x$ & $x$ & & $x$ & $x$ & $x$ & & 6 & $18.7 \%$ \\
\hline Support systems & & $x$ & $x$ & $x$ & $x$ & & & $x$ & 5 & $15.6 \%$ \\
\hline Student learning & & $x$ & & & & $x$ & $x$ & $x$ & 4 & $12.5 \%$ \\
\hline Teaching and learning activities & & $x$ & & $x$ & & & $x$ & $x$ & 4 & $12.5 \%$ \\
\hline Site visits & & $x$ & & $x$ & & & $x$ & & 3 & $9.4 \%$ \\
\hline Mentor: peer mentor & $x$ & $x$ & & $x$ & & & & & 3 & $9.4 \%$ \\
\hline ECP co-ordination & $x$ & $x$ & & & & & & & 2 & $6.3 \%$ \\
\hline Peer tutor & & $x$ & & $x$ & & & & & 2 & $6.3 \%$ \\
\hline 'At risk' student management/identification & $x$ & & & & & & & & 1 & $3.1 \%$ \\
\hline ECP workshops & & $x$ & & & & & & & 1 & $3.1 \%$ \\
\hline Language of discipline & & & & & & $x$ & & & 1 & $3.1 \%$ \\
\hline Total & & & & & & & & & 32 & $100 \%$ \\
\hline
\end{tabular}

\subsubsection{Lecturers' role in supporting ECP}

The lecturer participants all felt that their main role was to teach ECP students. Two of the participants had leadership roles in which they co-ordinated the ECP activities among ECP lecturers. The importance of supporting ECP came out quite strongly in the responses, as participants all had a responsibility for ensuring that ECP students progressed to the 
mainstream offerings in the faculty. Participants thus had many roles in supporting ECP students. Three participants said that they played the role of mentor, and another three participants found extra activities in the form of site visits and community engagement, an enabler to assist student learning. One department addressed the issue of language playing a vital role, and stated the following:

I have realised that I need to become a teacher in the language of my discipline, in this case Horticulture, as well as of its concepts and content. I became more familiar with the language and learning aspects needs of my students for whom English is not a first language (Dept F).

Table 2 provides themes identified in the lecturers' responses on the mechanisms to support ECP students.

Table 2 Lecturers' perceptions of the support mechanisms for ECP students, by department

\begin{tabular}{|c|c|c|c|c|c|c|c|c|c|c|}
\hline Support mechanism & A & B & C & D & $\mathbf{E}$ & $\mathbf{F}$ & $\mathbf{G}$ & $\mathbf{H}$ & Total & $\begin{array}{c}\text { Percentage } \\
\%\end{array}$ \\
\hline Tutorials & & $x$ & $x$ & $x$ & & & $x$ & $x$ & 5 & $17.8 \%$ \\
\hline Peer mentor programme & & $x$ & & $x$ & & & & $x$ & 3 & $10.7 \%$ \\
\hline Teaching methods/tools & $x$ & & & & & & $x$ & & 2 & $7.1 \%$ \\
\hline Fundani and communication skills & & $x$ & $x$ & & & & & & 2 & $7.1 \%$ \\
\hline Student counselling & & $x$ & $x$ & & & & & & 2 & $7.1 \%$ \\
\hline One-on-one interaction/consultation & & & & & $x$ & & $x$ & & 2 & $7.1 \%$ \\
\hline Workshops & & & & & $x$ & & & $x$ & 2 & $7.1 \%$ \\
\hline More time available & $x$ & & & & & & & & 1 & $3.6 \%$ \\
\hline Revision & $x$ & & & & & & & & 1 & $3.6 \%$ \\
\hline IL & & $x$ & & & & & & & 1 & $3.6 \%$ \\
\hline Academic enhancement questionnaire (AEQ) & & $x$ & & & & & & & 1 & $3.6 \%$ \\
\hline ECP co-ordinator & & $x$ & & & & & & & 1 & $3.6 \%$ \\
\hline Site visits & & $x$ & & & & & & & 1 & $3.6 \%$ \\
\hline Group work & & & & & $x$ & & & & 1 & $3.6 \%$ \\
\hline Learners steer lectures & & & & & $x$ & & & & 1 & $3.6 \%$ \\
\hline Social media: Facebook & & & & & & $x$ & & & 1 & $3.6 \%$ \\
\hline Language interaction & & & & & & & & $x$ & 1 & $3.6 \%$ \\
\hline Total & & & & & & & & & 28 & $100 \%$ \\
\hline
\end{tabular}

The responses show that participants recognise the importance of supporting ECP students using various methods. It is clear that emphasis is placed on supporting ECP students using the activities that were highlighted. Tutorials were identified as the main means of support, followed by the peer mentoring programme. IL support did not feature very strongly as a means of supporting ECP students. However, in the literature review (Besara \& Kinsley 2011: 418, Corrall 2010: 571, Massis 2012: 90, Shepley 2009: 91, Tenkasi \& Boland 1996: 88, Veal \& Bennett 2009: 162) and later in other responses, it is felt very strongly that IL is vital for developing and supporting students.

\subsubsection{Use of LMS}

The departments were asked whether they were currently using the Blackboard system. Six departments indicated that they were. Two departments responded that they were not. Respondents who said they were not using Blackboard were asked for reasons for not doing so. Of the two departments who indicated that they were not currently using Blackboard, $\mathrm{H}$ stated that it was "currently setting it up" and F was discouraged because: "...the internet server was very slow. We had to cancel [the Blackboard training session] while we were busy training".

Departments were asked to explain for what purposes they were using Blackboard. Six departments used Blackboard for teaching, four used it for communicating with students, and three used it for student progress reports such as uploading test marks. None of the departments indicated that they used it for their own research or to collaborate with colleagues or the librarian.

Departments had an opportunity to voice their perceptions, experiences and knowledge of the Blackboard system. Table 3 represents the themes from the responses. The two themes that emerged strongly were those of Blackboard as a communication platform and lecturers' average Blackboard knowledge.

Department A raised the importance of reliable technology:

I feel there is a place in the academic field for Blackboard if the technology to support it is at all times reliable and students have access to it (in other words, enough computer resources). 
From the responses below, it can be seen that $50 \%$ of departments share negative and $50 \%$ of departments share positive experiences of using Blackboard. Some of the negative experiences were login and registration problems, and the indication that Blackboard was not ideal for practical exercises. Some of the positive experiences were that it was an ideal platform for assignments and communication and that it made marking easier.

Table 3 Lecturers' perceptions, knowledge and experience of Blackboard

\begin{tabular}{|c|c|c|c|c|c|c|c|c|c|c|}
\hline Perception, knowledge and/or experience & A & B & C & D & E & $\mathbf{F}$ & G & H & Total & $\begin{array}{c}\text { Percentage } \\
\%\end{array}$ \\
\hline Communication platform & & $x$ & $x$ & $x$ & $x$ & & $x$ & & 5 & $17.8 \%$ \\
\hline Average Blackboard knowledge & & $x$ & $x$ & & $x$ & $x$ & & $x$ & 5 & $17.8 \%$ \\
\hline Good experience & $x$ & $x$ & $x$ & $x$ & & & & & 4 & $14.3 \%$ \\
\hline Bad experience & $x$ & & $x$ & $x$ & $x$ & & & & 4 & $14.3 \%$ \\
\hline Teaching tool & & $x$ & $x$ & $x$ & $x$ & & & & 4 & $14.3 \%$ \\
\hline Above average Blackboard knowledge & $x$ & & & $x$ & & & $x$ & & 3 & $10.7 \%$ \\
\hline Reliability of technology & $x$ & & & & & & & & 1 & $3.6 \%$ \\
\hline Positive perception & $x$ & & & & & & & & 1 & $3.6 \%$ \\
\hline Organise teaching resources & & $x$ & & & & & & & 1 & $3.6 \%$ \\
\hline Total & & & & & & & & & 28 & $100 \%$ \\
\hline
\end{tabular}

With regard to knowledge of Blackboard, three departments reported that their knowledge was "above average", and five departments reported it as "average". A comment was made that departments needed to use Blackboard. Department E commented as follows:

So, with Blackboard we basically only use it for uploading of marks, notifications, and uploading of exercises and lecture notes. We have to ... it's prescribed by the department. They need to see that we have a web presence.

It emerged strongly from the responses that Blackboard is a good communication and teaching tool. Menkhoff et al. (2011: 134) and Tenkasi and Boland (1996: 88-89) both claim that lecturers using online learning environments enhance learning experiences among students and enable knowledge sharing between lecturers and students. Barker (2006: 230) suggests that there is a need to form "virtual communities" as a way of improving active participation in the classroom. It is strongly evident in the comments above that there is a great need by lecturers for training on the Blackboard system and providing them with the necessary Information Technology support. As Crocker (2006: 4) suggests, in order for a well-established blended learning strategy to be implemented in South Africa, proper training and Information Technology support is imperative to enhancing the student learning experience.

\subsubsection{Knowledge sharing with faculty librarians}

Departments were asked how ideas and knowledge were being shared with the faculty librarian. The study found that email and face-to-face meetings were the main mode of sharing ideas and knowledge with the faculty librarian.

\subsubsection{Perceptions of library support services to ECP}

Departments were asked about what they perceived the librarian's role to be in supporting ECP students. Most departments saw the librarian's role as providing information support and assistance with assignments to students. Three departments saw the librarian's role as being vital to supporting ECP students. One department stated that the librarian could take over the teaching of communication skills in the faculty. Some of the comments from departments about the role of the librarian were as follows:

To help the students, because as lecturers we are more focused on the content. So, if the librarian now can help us or help the student with how to do research using the journal articles, and providing access to the textbooks that are available (Dept C).

That $\mathrm{IL}$ course is an absolutely vital one; also to assist with... doing assignments, accessing information, and being able to fulfil some of the [teaching] tasks (Dept D).

The librarian could actually take over communication skills; seriously they've got such a big role to play ... just the search for information, the analysis of questions, even the process of writing. They've got such a huge role to play in not just ECP students, but all students' academic career (Dept E). 
The findings support the literature review which indicated that lecturers, despite slow uptake, have recognised the important role of the faculty librarian as one that adds value to the teaching curriculum (Shepley 2009: 91, Veal \& Bennett 2009: 163).

\subsection{Findings from the faculty librarian}

The second round of data collection was to establish the librarian's perceptions and experience of collaborating with lecturers to support ECP students in teaching and learning via Blackboard. The following section summarises and discusses the findings.

\subsubsection{Support for ECP}

The faculty librarian was asked to describe his role. The themes identified from the response were those of assisting in finding information and of IL training. In comparison, the main themes that lecturers expressed were those of teaching, supporting, assisting, doing extra activities, co-ordinating, mentoring, and doing site visits. Both lecturers and librarian roles are important in supporting ECP students. The librarian was asked how he supported ECP students. The theme that stood out from his response was that of consulting with lecturers. In the lecturers' response to this question, only one department highlighted IL - which is offered by the faculty librarian as a support mechanism for ECP students. In contrast, the faculty librarian was asked what strategies were used to ensure ECP student success. The theme identified with regard to strategies used was IL training. As highlighted in responses by lecturers, they find their internal strategies more important, with tutorials, practical and additional support or revision being the main strategies. Support from other units at the institution such as The Fundani Centre for Higher Education Development (CHED), which supports lecturers with teaching, student counselling and the library (IL), featured very low.

The faculty librarian was asked to describe how the workshops held for lecturers support ECP students. The theme identified from the response was that attending ECP workshops was beneficial. Lecturers agreed strongly in their responses that workshops assisted and enhanced teaching methods, particularly with reference to teaching skills and strategies. The faculty librarian was asked whether any implementation ensued after attending ECP workshops and if so, to give one example. He responded that the requests from lecturers with regard to $\mathrm{IL}$ training increased after attending ECP workshops and departmental meetings. However, only six departments indicated that they implemented strategies after attending ECP workshops, and these were mainly subject-specific, with no mention of IL requests. The two other departments did not implement any ECP strategies as they claimed those workshops were more theory-based than practical. The faculty librarian was asked how attendance at departmental and faculty board meetings supported ECP students, and responded that it was the platform at which to market the library and services, especially IL training. Table 4 highlights the themes identified from the faculty librarian's responses to supporting ECP students.

Table 4 Librarian's interview: themes on supporting extended curriculum programme students

\begin{tabular}{|c|c|}
\hline Themes & Selected quotations \\
\hline $\begin{array}{l}\text { Assist in finding } \\
\text { information }\end{array}$ & "I assist them in finding information in the library" \\
\hline IL Training & $\begin{array}{l}\text { "The LIS service has got a policy where IL in modules or in certificate programme are offered to students and I make use } \\
\text { of those programs" } \\
\text { "With the aid of assignments I do the training with the students" }\end{array}$ \\
\hline Consultation with lecturers & $\begin{array}{l}\text { "I do consult with the lecturing staff and, depending on their additional needs I fit [these] needs into the training } \\
\text { programme" }\end{array}$ \\
\hline $\begin{array}{l}\text { Attending ECP workshops } \\
\text { are beneficial }\end{array}$ & $\begin{array}{l}\text { "Those workshops, I feel, [are] necessary because for some reason the ECP lecturing staff in my opinion shows high } \\
\text { turnover so that you don't sit with the same lecturing staff all the time and you don't want to reinvent the wheel every tim } \\
\text { - so it is good to sit in one group where the new staff are also introduced and you meet them face-to-face" }\end{array}$ \\
\hline $\begin{array}{l}\text { Marketing library services } \\
\text { at departmental and faculty } \\
\text { board meetings }\end{array}$ & $\begin{array}{l}\text { "Sitting in the faculty board, when you give information to the audience, of the other mainstream courses, lecturing staff } \\
\text { put up their hands and say but they didn't know about this intervention from the library. So, although we talk about it, } \\
\text { interventions for ECP sake, that is the focus area, there is a pickup of [these] interventions from other lecturers for their } \\
\text { students as well and it's not only for first years, it's right through. It's first, second, third years, even BTechs and even } \\
\text { sometimes postgraduate students, because postgraduate students may have left the institution five-ten years ago and } \\
\text { they come back and they're not fully in touch with how the libraries [have] evolved in their absence". }\end{array}$ \\
\hline
\end{tabular}

As stated earlier, the literature review identified the vital role that IL plays in supporting teaching and learning. The faculty librarian emphasised the increase in requests from lecturers for IL training, especially after attending departmental and faculty board meetings. These meetings are where lecturers are alerted to the faculty librarian's role, and what the library offers. Another very important point highlighted by the faculty librarian is consultation with lecturers. The importance of lecturers and the librarian working together to support student learning has been emphasised in the literature review. As Thomas and Saib (2013: 8) state, through successful collaboration between the lecturers and librarian, IL was integrated into the curriculum of the DUT's engineering course. The building of the lecturer and librarian partnership was a result of the librarian's strategy which included: the librarian's flexibility in offering service, offering individual research support to lecturers, and responding proactively to information and research needs of lecturers. Individual meetings gave the librarian an opportunity to promote IL training. 


\subsubsection{Use of LMS to share knowledge}

The faculty librarian was asked to describe his perception, knowledge and experience of Blackboard. He saw Blackboard as an educational tool providing students with access to information and commented that:

The Blackboard educational tool in my mind is an electronic tool that lecturing staff use to further assist students, but also that lecturers use to give information to students. So students can, on a twenty-four-hour basis, get information from the lecturer via the information on the Blackboard system. Obviously, with me being present on the lecturers' page - me being the library - students also have unlimited access to resources of the library.

Lecturers, on the other hand, perceived Blackboard as a communication platform and claimed that their knowledge of Blackboard is average.

The faculty librarian added that he was linked to lecturers' Blackboard pages, though only six of the eight departments interviewed were using Blackboard. The faculty librarian said that he mainly used his presence on the lecturers' Blackboard pages for informing students about IL and library resources. The faculty librarian was asked whether he thought it was important to use Blackboard and why. He had mixed feelings about the use of Blackboard, and commented:

The importance of using Blackboard: I'm a bit fifty-fifty ... because, remember, I'm talking about library information and CPUT's library information is available on the internet as well so it is not [necessary] for it to be located on one side only and then Blackboard is meant for interaction between lecturing staff and their students. So, although, I am glad to have presence there, I'm not too certain whether my presence on their Blackboard is really that helpful.

All academic departments thought that using Blackboard was important.

\subsubsection{LMS as a training and communication tool}

The faculty librarian was asked what his experience and perceptions were using Blackboard as an IL training tool. He found using Blackboard for IL training very useful and commented as follows:

That is the formal part where Blackboard, as a formal tool of the lecturer, has shown much promise, so the library's assessment program for the IL Certificate is present on Blackboard which is a formal tool, so that is very useful.

The literature review (Bennett \& Gilbert 2009: 135, Xiao 2010: 654) and responses by lecturers both emphasise that use of online learning environments increases student learning and interaction. The faculty librarian was asked how Blackboard was being used as an IL training tool. He saw it mainly as a formal tool and responded that "it is not only for assessment but for my [IL module] assessment".

\subsubsection{Blackboard as a lecturing tool to support student learning}

The faculty librarian was asked how Blackboard was supporting student learning. He felt it had more use as a lecturing tool. A follow-up question asked the faculty librarian's opinion on whether Blackboard enhanced teaching and learning. His response was that it was good for collaboration, explaining further that:

I feel it's a tool for the lecturing staff although, when I do the training, I do also act as the lecturer... Students need all the help they can get, so by doing the assignment-related training with them ... I, with the aid of the lecturer, give a list of resources for that particular assignment that students can use. That way, yes, it will be useful.

\subsubsection{Blackboard and student development and success}

The faculty librarian was then asked how the use of Blackboard as an IL training tool improved student development and success. He was in two minds about the use of Blackboard as an IL training tool for student development and success and commented that:

I would imagine that it is a useful tool ... all of the information is in any case available on the internet. So, to give an opinion that only Blackboard has done some development, I think would be overemphasising Blackboard as a tool because students are students with their own unique ways of getting information.

\subsubsection{Blackboard as a communication tool}

The faculty librarian was linked to three departments' Blackboard pages. The faculty librarian was asked which Blackboard features and tools he used. His response was that he mainly used the announcement tool, the content section 
to upload IL content, and the grade centre. The faculty librarian was asked when he used Blackboard to communicate with students, colleagues or the lecturers. Here he appeared to contradict himself by responding that he was not using it as a communication tool; in the previous response he had claimed that the announcement feature in Blackboard was used.

Three departments said they used Blackboard continuously to communicate with students, and three said they used it when they needed to notify students about assignments and tests. One department used Facebook continuously to communicate with students about assignments and tests as well as other class-related notifications.

The faculty librarian was asked whether he used the Blackboard Collaborate feature for IL training purposes or meetings with colleagues. His response was that, although he was aware of the feature, he was not using it. Only one department indicated that it was using Blackboard Collaborate for teaching.

A follow-up question asked the faculty librarian what he thought the advantages and disadvantages were of using Blackboard Collaborate. He responded that the main advantage was that it was a communication tool; a disadvantage was that technology issues hampered its use. This response was similar to the findings from lecturers who indicated that the main advantage of using Blackboard Collaborate is for online tutorials, the main disadvantage being unstable connectivity.

\title{
5.2.7 The future of the LMS for sharing library resources and knowledge
}

The faculty librarian was then asked whether he would consider using Blackboard Collaborate in future. His response was:

\begin{abstract}
That part I don't know. ... I do feel that [...] the instrument Blackboard as such may be overrated because there are other communication devices on the market which could be cheaper. There's Facebook, there's Google which has got a video call centre, there's Skype. So, there are other communication devices similar to Blackboard that [are] available that a person could possibly use for the same purpose. But would you consider using the Blackboard Collaborate feature in future? It will definitely be one of the tools, yes.
\end{abstract}

In comparison, the majority of departments indicated that they would make use of Blackboard Collaborate in the future. However, one department emphasised that the use of Facebook was advantageous as all students had a Facebook account and active participation took place.

\section{Recommendations}

The recommendations can be divided into two main categories, one focusing on items for practice and the other on areas for future research.

\subsection{Recommendations for practice}

This study has highlighted the importance of blended learning as well as how lecturers and faculty librarians can collaborate to support it through sharing knowledge in the online learning environment. The study endorses Knight's (2013: 765) recommendation that collaboration between lecturers and librarians needs to be maintained to ensure relevant information acquisition for supporting the curriculum. One approach would be to include lecturers in collection development. However, communication and current awareness, and staff training have been identified as essential to supporting teaching and learning through the use of the online learning environment. Asogwa, Ugwu and Ugwuanyi (2015: 1146) emphasised that a combination of good information and communications technology (ICT) infrastructure and skilled lecturing and library staff make a significant difference in student experience in the online learning environment and in retrieving reliable information.

The following recommendations are made for CPUT to enhance teaching and learning and to strengthen the knowledge culture:

- The E-learning department should provide training sessions on Blackboard for lecturers during less busy periods.

- Workshops should be less theoretical and more practical.

- Regular updates of Blackboard should be marketed by the E-learning department.

- Dedicated IT staff should be available to support lecturers and librarians on Blackboard.

- Librarians and lecturers should explore the use of Blackboard Collaborate for meetings and to share knowledge and expertise.

\subsection{Recommendations for future studies}

For the librarian and libraries to remain relevant in the world of technology and information overload, keeping up to date with new trends is imperative. It is vital for new studies to be conducted in the future. The researchers recommend the following studies:

- The ECP student experience of online learning environments and library support.

- A follow-up study on Faculty A using this study's baseline data. 
- $\quad$ All CPUT faculties and faculty librarians' perceptions and experiences of using the online learning environment as a knowledge management tool.

- Universities of Technology in South Africa to investigate in a comparative study how embedded librarians use Blackboard or another LMS as a knowledge management tool to support blended learning.

- Implementation of innovative technology infrastructure in higher education, moving to cloud computing and exploring artificial intelligence, integrated systems and discovery tools.

- $\quad$ Comparing best practices among university communities in the area of online learning environments.

\section{Conclusion}

This study sought to investigate how CPUT Libraries could contribute to knowledge management processes in an online learning environment with the use of Blackboard and by embedding the librarian to support blended learning. Communication, current awareness and staff training have been identified as crucial in succeeding to support teaching and learning through the use of the online learning environment. Although this is a study within only one faculty at CPUT, where the uptake of Blackboard was still quite limited, the researchers believe that other universities could benefit from the insights that have emerged from it.

The study attempted to address the research problem which was to investigate knowledge sharing between lecturers and librarians using online learning environments to support first-year Extended Curriculum Programme students. The lecturers were positive about working together with the faculty librarian to support ECP students and agreed that the collaboration was necessary. The faculty librarian acknowledged the lecturers' wealth of knowledge, thus aligning with Maponya's (2005: 901) analysis of the literature that concluded that the academics' knowledge is valued with regard to knowledge management in higher education. Collaboration between the lecturers and the librarian mainly took place in relation to IL, assignments, and general availability of resources. The librarian was sceptical about his role at ECP workshops. The lecturers, on the other hand, thought it was a good opportunity for the librarian to gain an understanding of the ECP programme. They were of the opinion that his attendance would help him to assist lecturers in supporting ECP students. Departments thought the workshops were the ideal forum in which to share knowledge with the librarian. Both the librarian and lecturers met quite often; only one department indicated not meeting with the librarian at all. Blackboard was, however, found not to be a topic discussed between lecturers and the librarian. Still, the librarian was linked to the Blackboard pages of three departments for the purpose of communicating with students, uploading the IL modules and for online assessment. Although lecturers and the librarian thought that Blackboard improved student learning, both were aware of other means of reaching the students online - Facebook being one platform used by some departments and Google another.

Although collaboration between lecturers and librarians have proven to be successful in achieving overall institutional goals, building good working relationships takes a long time and requires commitment from both parties (Chipeta, Jacobs \& Mostert 2009: 55, Shen 2012:14). Nevertheless, librarians are consistently finding new ways of working with lecturers. While there is clearly room for more collaboration at CPUT, there is a good working relationship overall between lecturers and the librarian with regard to supporting ECP students. It was found that knowledge sharing took place during meetings, but not via Blackboard. It is, therefore, important that parties seeking collaboration create an appropriate platform for interaction as well as continue to use other opportunities, not necessarily supported directly by ICTs, for interaction.

\section{References}

Aharony, N. 2011. Librarians' attitudes toward knowledge management. College \& Research Libraries, 72 (2): 111 -126.

Anderson, K. and May, F. 2010. Does the method of instruction matter? An experimental examination of IL instruction in the online, blended, and face-to-face classrooms. The Journal of Academic Librarianship, 36(6): 495-500.

Asogwa,B.E., Ugwu, C.I. and Ugwuanyi, F.C. 2015. Evaluation of electronic service infrastructures and quality of eservices in Nigerian academic libraries. The Electronic Library, 33(6): 1133-1149.

Ball,S., Leonard, L., Littlejohn, A., Kelly, J., McAteer, E. McCulloh, M. and Peacock, S. 2012. Effective use of virtual learning environments. [Online]. http://www.jiscinfonet.ac.uk/InfoKits/effective-use-of-VLEs (2 March 2012).

Barker, R. 2006. Homo machinus versus Homo sapiens: A knowledge management perspective of virtual communities in cyberspace. Communicatio: South African Journal for Communication Theory and Research, 32(2): 226-240.

Bennett, O. and Gilbert, K. 2009. Extending liaison collaboration: partnering with faculty in support of a student learning community. Reference Services Review, 37(2): 131-142.

Besara, R. and Kinsley, K. 2011. Academic libraries - measuring up: assessment and collaboration for student success. New Library World, 112(9/10): 416-424.

Bhavnagri, N. P. and Bielat, V. 2005. Faculty-librarian collaboration to teach research skills: electronic symbiosis. The Reference Librarian, 43(89-90): 121-138.

Chipeta, G., Jacobs, D. and Mostert, J., 2009. Teaching and learning of IL in some selected institutions of higher learning in KwaZulu-Natal and Malawi. South African Journal of Libraries and Information Science, 75(1): 46-57.

Clarence-Fincham, J., 2009. Developing an extended curriculum for humanities at the University of KwaZulu-Natal: conceptual shifts, challenges and constraints. Journal for New Generation Sciences, 7(3): 70-83.

Clark, V. and Creswell, J. 2011. Designing and conducting mixed methods research. Los Angeles, CA: Sage.

Comba, V. 2009. E-Tutorships and e-learning: re-skilling librarians for interactive communication in virtual environments. In Strategies for regenerating the library and information profession. J. Varlejs and G. Walton, Eds. Munich: Saur. 
[Online].

http://www.degruyter.com/dg/viewbooktoc.chapterlist.resultlinks.fullcontentlink:pdfeventlink/\$002fbooks $\$ 002 f 9783598$ 441776\$002f9783598441776.5.279\$002f9783598441776.5.279.pdf?t:ac=product/41985 (23 October 2014).

Coopman, S. 2009. A critical examination of Blackboard's e-learning environment. First Monday, 14(6). [Online]. http://journals.uic.edu/ojs/index.php/fm/article/view/2434/2202 (18 July 2016).

Corrall, S. 2010. Educating the academic librarian as a blended professional: a review and case study. Library Management, 31(8/9): 567-593.

Costello, B., Lenholt, R. and Stryker, J., 2004. Using Blackboard in library instruction: addressing the learning styles of Generations $X$ and Y. The Journal of Academic Librarianship., 30 (6): 452-460.

CPUT. 2008. Fundani: Extended curriculum programme: resources for Extended Curriculum Programme. [Online]. http://www.cput.ac.za/services/fundani/extended (3 March 2012).

CPUT. 2016a. Vision and Mission. [Online]. http://www.cput.ac.za/about/vision (19 July 2016).

CPUT. 2016b. About the Centre for e-Learning. [Online]. http://www.cput.ac.za/services/elearning (19 July 2016).

Crocker, A. 2006. Blended learning: a new approach to legal teaching in South African law schools. Journal for Juridical Science, 31(2): 1-25.

Garraway, J. 2009. Success of foundation (extended programmes) in Engineering and Sciences at CPUT. In Success stories in foundation / extended programmes. Higher Education Learning \& Teaching Association of Southern Africa. [Online]. http://www.cput.ac.za/blogs/ecp/files/2015/02/Final_Success-Stories.pdf (18 July 2016).

Goh, A. 2005. Harnessing knowledge for innovation: an integrated management framework. Journal of Knowledge Management, 9(4): 6-18.

Hightower, B., Rawl, C. and Schutt, M., 2007. Collaborations for delivering the library to students through WebCT. Reference Services Review, 35 (4): 541-551.

Hoffman, S. 2011. Embedded academic librarian experiences in online courses: roles, faculty collaboration, and opinion. Library Management, 32(6/7): 444-456.

Jain, P. 2007. An empirical study of knowledge management in academic libraries in East and Southern Africa. Library Review, 56 (5): 377-392.

Kille, A. 2006. Wikis in the workplace: how wikis can help manage knowledge in library reference services. Libres, 16(1): 89-108.

Kleinveldt, L. 2015. The role of the embedded librarian using Blackboard as a knowledge management tool to support blended learning at the Cape Peninsula University of Technology (CPUT) Libraries. Master's thesis. University of Pretoria.

Knight, N. 2013. Enhancing access to library resources at Northern Caribbean University through an e-library initiative. The Electronic Library, 31(6): 753-769.

Lave, J. and Wenger, E. 1991. Situated learning: legitimate peripheral participation. Cambridge: Cambridge University Press.

Levy, S. 2003. Six factors to consider when planning online distance learning programs in higher education. Online Journal of Distance Learning Administration, 6(1): 1-19.

Liu, K., Chang, C. and Hu, I., 2010. Exploring the effects of task characteristics on knowledge sharing in libraries. Library Review, 59 (6): 455-468.

Maponya, P. 2005. Fostering the culture of knowledge sharing in higher education. South African Journal of Higher Education, 19(5): 900-911.

Massis, B. 2012. Librarians and faculty collaboration-partners in student success. New Library World, 113(1/2): 90-93.

Mavodza, J. 2011. The academic librarian and the academe. New Library World, 112 (9/10): 446-451.

Mavodza, J. and Ngulube, P. 2012. Knowledge management practices at an institution of higher learning. South African Journal of Information Management, 14(1): 1-8.

Menkhoff, T., Thang, T.Y., Chay, Y.W. and Wong, Y.K. 2011. Engaging knowledge management learners through webbased ICT: an empirical study. VINE, 41(2): 132-151.

Moll, M. and Kleinveldt, L. 2008. The Mahout on the elephant: how the knowledge management practices of the Wellington Campus Library enriches CPUT Libraries. Library Papers and Reports. [Online]. http://works.bepress.com/michiel moll/9/ (23 October 2014).

Naidoo, S. and Raju, J., 2012. Impact of the digital divide on IL training in a higher education context. South African Journal of Libraries and Information Science, 78(1): 34-44.

Ngulube, P., 2005. Improving the quality of research outputs in higher education through knowledge sharing and collaboration: a case study. Mousaion, 23(1): 39-61.

Nielsen, D. and McCabe, K. 2012. Embedded librarian: enhancing student education through collaboration. British Columbia Library Association Browser: Linking the Library Landscape, 4(2) [Online]. http://bclabrowser.ca/bcla2/index.php/browser/article/viewArticle/384 (23 October 2014).

Nonaka, I. and Takeuchi, H. 1995. The knowledge creating company: how Japanese companies create the dynamics of innovation. New York: Oxford University Press.

Oakleaf, M., Millet, M. and Kraus, L. 2011. All together now: getting faculty, administrators, and staff engaged in IL assessment. portal: Libraries and the Academy, 11(3): 831-852.

Rafaeli, S., Barak, M., Dan-Gur,Y. and Toch, E. 2004. QSIA - a Web-based environment for learning, assessing and knowledge sharing in communities. Computers and Education, 43: 273-289 
Sandrock, J. 2011. Art of KM CoP clustering exercise. [Online video]. http://www.youtube.com/watch?v=Pye7VvL4Col (13 April 2016).

Shen, L., 2012. Improving the effectiveness of librarian-faculty collaboration. Collaborative Librarianship, 4(1):14-22.

Shepley, S. 2009. Building a virtual campus: librarians as collaborators in online course development and learning. Journal of Library Administration, 49(1-2): 89-95.

Si, L., Xing, W., Zhou, L. and Liu, S. 2012. Embedded services in Chinese academic libraries. The Journal of Academic Librarianship, 38(3): 175-182.

Silverman, D. 2011. Qualitative research. $3^{\text {rd }}$ ed. London: Sage.

Tee, M. and Karney, D., 2010. Sharing and cultivating tacit knowledge in an online learning environment. International Journal of Computer-Supported Collaborative Learning, 5(4): 385-413.

Tenkasi, R. and Boland, R.J. 1996. Exploring knowledge diversity in knowledge intensive firms: a new role for information systems. Journal of Organizational Change Management, 9(1): 79-91.

The University of North Carolina. 2010. Distance education services: embedded librarian. [Online]. http://library.uncg.edu/info/distance_education/embedded_librarian.aspx (4 August 2012).

Thomas, D. and Saib, M. 2013. Collaboration between academics and librarians: the case of the Durban University of Technology. Proceedings of the $34^{\text {th }}$ International Association of Scientific and Technogical University Libraries (IATUL) Conference. 15-18 April 2013. Cape Town, South Africa. [Online]. http://docs.lib.purdue.edu/iatul/2013/papers/40/ (23 October 2014).

Tu, C. 2002. The measurement of social presence in an online learning environment. International Journal on E-learning, $1(2): 34-45$.

Veal, R. and Bennett, E. 2009. The virtual library liaison: a case study at an online university. Journal of Library Administration, 49(1-2): 161-170.

Xiao, J. 2010. Integrating IL into Blackboard: librarian-faculty collaboration for successful student learning. Library Management, 31(8/9): 654-668.

Yen, C. H., Chen, I. C., Lai, Su. C., and Chuang, Y. R. 2015. An analytics-based approach to managing cognitive load by using log data of Learning Management Systems and Footprints of social media. Educational Technology and Society, 18 (4), 141-158. 